\begin{tabular}{|c|c|c|c|c|c|c|}
\hline Characteristics & $\begin{array}{l}\text { BF\% } \\
\text { Normal } \\
\text { fat } \\
(n=309)\end{array}$ & $\begin{array}{l}\text { Overfat } \\
(n=148)\end{array}$ & $P$ & $\begin{array}{l}\text { Non- } \\
\text { sarcopenia } \\
(n=405)\end{array}$ & $\begin{array}{l}\text { SMMI } \\
\text { Sarcopenia } \\
(n=52)\end{array}$ & $P$ \\
\hline Female, n (\%) & $\begin{array}{l}253 \\
(81.9)\end{array}$ & $\begin{array}{l}125 \\
(84.5)\end{array}$ & 0.494 & $353(87.2)$ & $25(48.1)$ & $<0.001$ \\
\hline $\begin{array}{l}\text { Age, yrs, median } \\
\text { (IQR) }\end{array}$ & $\begin{array}{l}49 \\
(37 \sim 58)\end{array}$ & $\begin{array}{l}54 \\
(48 \sim 61)\end{array}$ & $<0.001$ & $50(41 \sim 58)$ & 57 (27 63) & 0.397 \\
\hline $\begin{array}{l}\text { Disease duration, } \\
\text { month, median } \\
\text { (IQR) }\end{array}$ & $\begin{array}{l}48 \\
(24 \sim 96)\end{array}$ & $\begin{array}{l}64 \\
(27 \sim 141)\end{array}$ & 0.005 & $\begin{array}{l}52 \\
(24 \sim 108)\end{array}$ & $\begin{array}{l}66 \\
(24 \sim 129)\end{array}$ & 0.382 \\
\hline $\begin{array}{l}\text { Positive RF, n } \\
\text { (\%) }\end{array}$ & $\begin{array}{l}203 \\
(65.7)\end{array}$ & $97(65.5)$ & 0.974 & $259(64.0)$ & $41(78.8)$ & 0.033 \\
\hline $\begin{array}{l}\text { Positive ACPA, n } \\
\text { (\%) } \\
\text { Core disease } \\
\text { activity indicators }\end{array}$ & $\begin{array}{l}212 \\
(68.6)\end{array}$ & $\begin{array}{l}105 \\
(70.9)\end{array}$ & 0.612 & 283 (69.9) & $34(65.4)$ & 0.508 \\
\hline $\begin{array}{l}\text { 28TJC, median } \\
\text { (IQR) }\end{array}$ & $2(0 \sim 5)$ & $2(0 \sim 8)$ & 0.145 & $2(0 \sim 5)$ & $4(0 \sim 9)$ & 0.091 \\
\hline $\begin{array}{l}\text { 28SJC, median } \\
\text { (IQR) }\end{array}$ & $1(0 \sim 4)$ & $1(0 \sim 4)$ & 0.248 & $1(0 \sim 4)$ & $2(0 \sim 8)$ & 0.200 \\
\hline $\begin{array}{l}\text { ESR, (mm/h), } \\
\text { median (IQR) }\end{array}$ & $\begin{array}{l}26 \\
(15 \sim 44)\end{array}$ & $\begin{array}{l}32 \\
(15 \sim 52)\end{array}$ & 0.133 & $26(14 \sim 45)$ & $42(26 \sim 74)$ & $<0.001$ \\
\hline $\begin{array}{l}\mathrm{CRP},(\mathrm{mg} / \mathrm{L}) \text {, } \\
\text { median (IQR) }\end{array}$ & $\begin{array}{l}3.8 \\
(3.3 \sim 12.9)\end{array}$ & $\begin{array}{l}5.4 \\
(3.3 \sim 20.0)\end{array}$ & 0.008 & $\begin{array}{l}3.8 \\
(3.3 \sim 12.4)\end{array}$ & $\begin{array}{l}15.5 \\
(5.2 \sim 32.8)\end{array}$ & $<0.001$ \\
\hline $\begin{array}{l}\text { DAS28-CRP, } \\
\text { median (IQR) }\end{array}$ & $\begin{array}{l}3.2 \\
(2.0 \sim 4.1)\end{array}$ & $\begin{array}{l}3.4 \\
(2.3 \sim 4.8)\end{array}$ & 0.043 & $\begin{array}{l}3.1 \\
(2.0 \sim 4.2)\end{array}$ & $\begin{array}{l}4.0 \\
(2.6 \sim 5.5)\end{array}$ & 0.003 \\
\hline $\begin{array}{l}\text { HAQ-DI, median } \\
\text { (IQR) }\end{array}$ & $\begin{array}{l}0.13 \\
(0 \sim 0.50)\end{array}$ & $\begin{array}{l}0.38 \\
(0 \sim 1.00)\end{array}$ & $<0.001$ & $\begin{array}{l}0.13 \\
(0 \sim 0.63)\end{array}$ & $\begin{array}{l}0.50 \\
(0.03 \sim 1.25)\end{array}$ & 0.002 \\
\hline $\begin{array}{l}\text { Functional } \\
\text { limitation, } n(\%)\end{array}$ & 38 (12.3) & 32 (21.6) & 0.010 & $53(13.1)$ & $17(32.7)$ & $<0.001$ \\
\hline $\begin{array}{l}\text { Radiographic } \\
\text { assessment }\end{array}$ & & & & & & \\
\hline $\begin{array}{l}\text { mTSS, median } \\
\text { (IQR) }\end{array}$ & $\begin{array}{l}11.0 \\
(3.8 \sim 32.5)\end{array}$ & $\begin{array}{l}16.5 \\
(6.6 \sim 50.8)\end{array}$ & 0.005 & $\begin{array}{l}12.0 \\
(4.0 \sim 32.5)\end{array}$ & $\begin{array}{l}24.0 \\
(10.0 \sim 79.8)\end{array}$ & 0.001 \\
\hline $\begin{array}{l}\text { JSN subscore, } \\
\text { median (IQR) }\end{array}$ & $\begin{array}{l}3.0 \\
(0 \sim 11.8)\end{array}$ & $\begin{array}{l}3.0 \\
(0 \sim 20.0)\end{array}$ & 0.158 & $\begin{array}{l}2.5 \\
(0 \sim 12.3)\end{array}$ & $\begin{array}{l}9.0 \\
(1.1 \sim 34.1)\end{array}$ & 0.001 \\
\hline $\begin{array}{l}\text { Erosion } \\
\text { subscore, median } \\
\text { (IQR) }\end{array}$ & $\begin{array}{l}9.0 \\
(2.5 \sim 21.0)\end{array}$ & $\begin{array}{l}11.8 \\
(6.0 \sim 29.8)\end{array}$ & 0.001 & $\begin{array}{l}9.5 \\
(3.0 \sim 21.0)\end{array}$ & $\begin{array}{l}19.0 \\
(6.1 \sim 47.6)\end{array}$ & 0.002 \\
\hline RJD, n (\%) & $\begin{array}{l}168 \\
(54.4)\end{array}$ & $95(64.2)$ & 0.047 & $225(55.6)$ & $38(73.1)$ & 0.016 \\
\hline
\end{tabular}

index (SMMI) $\leq 8.87 \mathrm{~kg} / \mathrm{m}^{2}$ in men and $\leq 6.42 \mathrm{~kg} / \mathrm{m}^{2}$ in women. Clinical data including disease activity, function and radiographic assessment were collected.

Results: There were 457 RA patients and 1,860 control subjects recruited. In RA patients, there were $17.7 \%, 58.0 \%, 20.1 \%$ and $4.2 \%$ with underweight, normal weight, overweight, or obesity respectively, and $32.4 \%$ were overfat, $11.4 \%$ with sarcopenia. Comparisons to control subjects in age and gender stratification showed that male RA patients had significantly lower BMI and SMMI with higher percentage of underweight and sarcopenia in almost all age subgroups; female patients had lower SMMI in all age subgroups and lower BMI with higher prevalence of sarcopenia but higher $\mathrm{BF} \%$ at age $\leq 30$ and $51-60$ years (all $\mathrm{P}<0.05$, figure 1). RA patients with sarcopenia had higher rate of functional limitation, higher disease activity indicators and radiographic scores (all $P<0.05$, table 1). Multivariate logistic regression analyses showed SMMI (OR=0.633, 95\% Cl: 0.507 0.790, $P<0.001)$ and sarcopenia $(O R=2.154,95 \% C l: 1.032 \sim 4.497, P=0.041)$ were associated with radiographic joint damage.

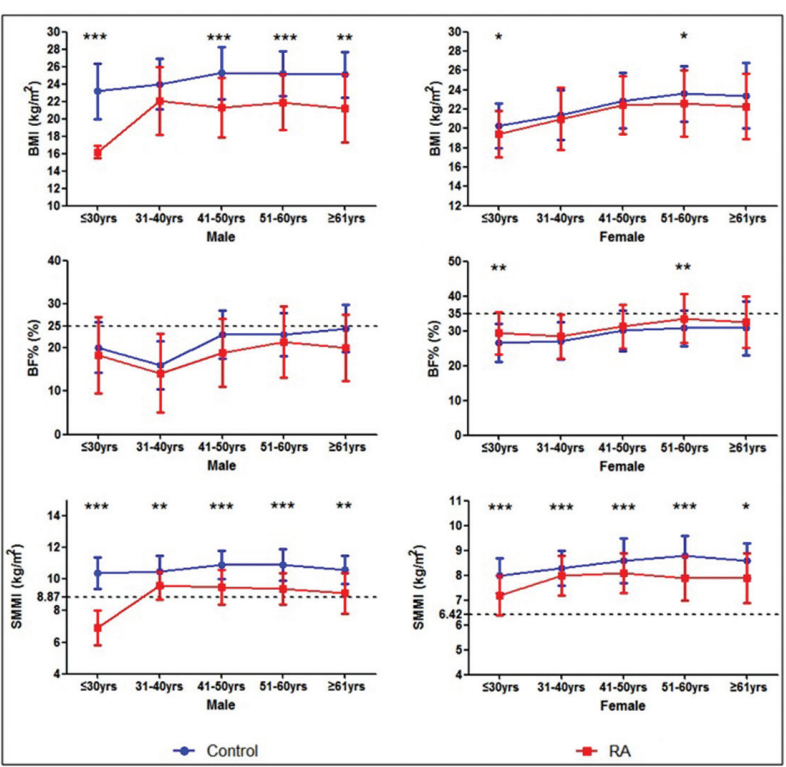

Figure 1. Comparison of $\mathrm{BMI}$ and $\mathrm{BC}$ between RA patients and control subjects in age and gender stratification. Underweight, $\mathrm{BMl}<18.5 \mathrm{~kg} / \mathrm{m}^{2}$; Normal weight, $18.5 \mathrm{~kg} / \mathrm{m}^{2}<\mathrm{BMl}<24 \mathrm{~kg} /$ $\mathrm{m}^{2}$; Overweight, $24 \mathrm{~kg} / \mathrm{m}^{2} \leq \mathrm{BMl}<28 \mathrm{~kg} / \mathrm{m}^{2}$; Obesity, BMl $\geq 28 \mathrm{~kg} / \mathrm{m}^{2}$; Overfat, BF\% $\geq 25 \%$ for men and $\geq 35 \%$ for women; Sacropenia, SMMl $\leq 8.87 \mathrm{~kg} / \mathrm{m}^{2}$ in men and $\leq 6.42 \mathrm{~kg} / \mathrm{m}^{2}$ in women; ${ }^{*} \mathrm{P}<0.05,{ }^{* *} \mathrm{P}<0.01,{ }^{* * *} \mathrm{P}<0.001$.

Conclusions: This study showed lower SMMI and higher prevalence of sarcopenia in RA patients which were positively associated with joint damage.

Disclosure of Interest: None declared

DOI: 10.1136/annrheumdis-2018-eular.6085

\section{SAT0100 THE DETERMINANTS OF REFRACTORY RHEUMATOID ARTHRITIS}

M. Bécède, J. Smolen, D. Aletaha. Department of Medicine 3, Division of Rheumatology, Medical University of Vienna, Vienna, Austria

Background: It is an ongoing matter of research, whether the course of rheumatoid arthritis (RA) can be altered by an early intervention, a concept historically referred to as the "window of opportunity". ${ }^{1}$ With the inherent challenge of underlying self-limiting disease in early patients, it remains unclear, whether the ultimate disease course of definite RA is really affected by the timing of initial treatment.

Objectives: To explore whether the long-term course of RA is different according to the delay of initial treatment.

Methods: Patients were identified from a longitudinal clinical database, and patients with refractory RA ("reRA") were compared with patients with treatment amenable RA ("taRA"). reRA was defined as $\geq 3$ treatment courses ( $\geq 1$ biological) over $\geq 18$ months since diagnosis without reaching low disease activity (LDA) or remission (REM) defined by a Clinical Disease Activity Index (CDAI, $\geq 10$ ); taRA patients reached at least LDA within their first 2 treatment courses. We performed both matched and adjusted logistic regression analysis to compare differences in timing of first treatment between these two groups.

Abstract SAT0100 - Table 1. Patient characteristics at first clinical visit.

\begin{tabular}{|c|c|c|c|c|c|c|c|c|}
\hline \multirow{2}{*}{$\begin{array}{l}\text { Features } \\
\text { Characteristics }\end{array}$} & \multicolumn{5}{|c|}{ Populations } & \multicolumn{3}{|c|}{ Differences $\left(\mathrm{p}\right.$-value $\left.{ }^{*}\right)$} \\
\hline & $\begin{array}{c}\text { reRA } \\
(\mathrm{n}=70)\end{array}$ & Other $(n=240)$ & $\begin{array}{c}\text { taRA } \\
(n=102)\end{array}$ & $\begin{array}{l}\text { reRA matched }{ }^{* *} \\
(n=50)\end{array}$ & $\begin{array}{l}\text { taRA matched }{ }^{\star *} \\
(\mathrm{n}=50)\end{array}$ & $\begin{array}{l}\text { Across all three } \\
\text { unmatched groups }\end{array}$ & $\begin{array}{l}\text { reRA vs taRA } \\
\text { (unmatched) }\end{array}$ & $\begin{array}{c}\text { reRA vs taRA } \\
\left(\text { matched }^{\star \star}\right)\end{array}$ \\
\hline First Visit (month/year) & $\begin{array}{c}12 / 2005 \\
(03 / 2002 ; 03 / \\
2009)^{\#}\end{array}$ & $\begin{array}{c}06 / 2006(08 / \\
2001 ; 08 / 2010)\end{array}$ & $\begin{array}{c}12 / 2009(10 / \\
2005 ; 11 / 2012)\end{array}$ & $\begin{array}{c}06 / 2007(12 / \\
2003 ; 07 / 2010)\end{array}$ & $\begin{array}{c}07 / 2007(09 / \\
2004 ; 08 / 2010)\end{array}$ & $<0.001$ & $<0.001$ & 0.786 \\
\hline $\begin{array}{l}\text { Time to First Treatment (years } \\
\text { from onset of symptoms) }\end{array}$ & $3.17(4.10)$ & $1.38(2.61)$ & $1.45(2.80)$ & $2.61(3.76)$ & $0.88(0.97)$ & $<0.001$ & 0.001 & 0.003 \\
\hline Female $(\%)$ & 92.9 & 75.4 & 70.6 & 94 & 70 & 0.002 & $<0.001$ & 0.002 \\
\hline Age at Symptom Onset (years) & $\begin{array}{c}44.37 \\
(14.44) \dagger\end{array}$ & $46.88(14.53)$ & $51.14(14.08)$ & $46.73(14.02)$ & $53.42(12.11)$ & 0.006 & 0.002 & 0.012 \\
\hline CDAI (0-76) & $26.06(12.22)$ & $17.94(12.49)$ & $15.39(9.81)$ & $25.36(11.98)$ & $16.93(9.42)$ & $<0.001$ & $<0.001$ & $<0.001$ \\
\hline
\end{tabular}

${ }^{*}$ ANOVA, $\mathrm{t}$-test, or $\mathrm{Chi}^{2}$, as appropriate; ${ }^{* *}$ matched for date of first clinical visit;

$\dagger$ mean (SD)/\% as applicable; \# date: median (quartiles) 
Results: We enrolled 412 patients, of whom 70 were reRA and 102 taRA; 240 patients fulfilled neither definition. As can be seen in table 1, reRA patients were more frequently female ( 92.9 vs. $70.6 \%$, p<0.001), younger (44.37 vs. 51.14 years, $p=0.002$ ), and had higher CDAl levels at first presentation (26.06 vs. 15.39 , $\mathrm{p}<0.001)$; time to first DMARD treatment was significantly longer for reRA than taRA ( 3.17 vs. 1.45 years, $p=0.001$ ). In a multivariate analysis, treatment delay also showed statistical significance $(p=0.007)$. After matching reRA with taRA patients for the date of their initial presentation at our clinic, treatment delay was significantly longer univariately $(p=0.013)$ and adjusted for other significant predictors $(p=0.027)$. As our matching allowance for calendar year was $+/-1$ year, we could only use 50 (of 70) identified reRA patients from the cohort study approach. Based on the significant predictors, a discriminative matrix model could be constructed (figure 1).

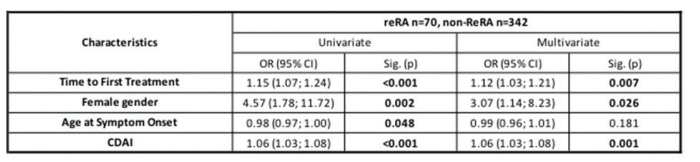

\begin{tabular}{|c|c|c|c|c|c|c|}
\hline & & & reRA vs. non-reR & & & \\
\hline \multirow{6}{*}{ Gender } & \multirow{3}{*}{ Female } & $10.6(2.8 ; 44.3)$ & 36.6 (18.4; 59.7) & $51.8(29.9: 72.9)$ & $>2$ years & \multirow{6}{*}{$\begin{array}{l}\text { Time to First } \\
\text { Treatment }\end{array}$} \\
\hline & & $3.4(0.8 ; 25.3)$ & $15.2(6.1 ; 33.3)$ & $25.1(11.2 ; 47.0)$ & $>1: \leq 2$ years & \\
\hline & & $2.1(0.5 ; 20.3)$ & $10.8(4.6 ; 23.3)$ & $18.6(9.0 ; 34.6)$ & sl year & \\
\hline & \multirow{3}{*}{ Male } & $3.1(0.5 ; 33.0)$ & $13.2(3.5 ; 45.9)$ & $22.1(6.6 ; 60.6)$ & $>2$ years & \\
\hline & & $0.9(0.1 ; 25.3)$ & $4.6(1.0 ; 24.9)$ & $8.3(2.0 ; 36.0)$ & $>1 ; \leq 2$ years & \\
\hline & & $0.6(0.1 ; 19.9)$ & $3.0(0.7 ; 18.4)$ & $5.8(1.5 ; 26.8)$ & sl year & \\
\hline & & REM/LDA $(\leq 10$ & $\begin{array}{l}\text { MDA }(>10, \leq 22 \\
\text { ease Activity (C) }\end{array}$ & $\begin{array}{l}\text { HDA (>22) } \\
\text { AAI) }\end{array}$ & & \\
\hline
\end{tabular}

Abstract SAT0100 - Figure 1. Comparing reRA vs non-reRA in a cohort study (logistic regression model) and predicting the probability of reRA including all selected baseline risk factors* in a matrix risk model

${ }^{*}$ Colour scheme: blue: $0 \%-5 \%$; green: $5.1 \%-15 \%$; orange: $15.1 \%-25 \%$; red: $>25 \%$ predicted probability of reRA; results are estimated for patient presenting in the year 2010

Conclusions: Our data suggest that delay to initial treatment affects the longterm course of RA. Earlier treatment initiation thus may change the severity of RA.

\section{REFERENCE:}

[1] Van Nies JAB, et al. What is the evidence for the presence of a therapeutic window of opportunity in rheumatoid arthritis? A systematic literature review. Ann Rheum Dis 2014;73(5):861-70.

Disclosure of Interest: None declared

DOI: 10.1136/annrheumdis-2018-eular.1925

\section{SAT0101 ATLANTOEPISTROPHIC MAGNETIC RESONANCE IMAGING INVOLVEMENT IN EARLY RHEUMATOID ARTHRITIS}

M. Carotti ${ }^{1}$, F. Salaffi ${ }^{2}$, M. Di Carlo ${ }^{2}$, F. Sessa ${ }^{1}$, A. Giovagnoni' ${ }^{1}{ }^{1}$ Clinic of Radiology, Università Politecnica delle Marche, Ancona; ${ }^{2}$ Rheumatological Clinic, Università Politecnica delle Marche, Jesi, Italy

Background: The involvement of the cervical spine in rheumatoid arthritis (RA) can be essential regarding prognosis and mortality. The early detection of a cervical spine involvement in RA is essential to avoid possibly fatal complications.

Objectives: To assess the involvement of the atlantoaxial joint in patients with early rheumatoid arthritis (ERA) to evaluate the role of magnetic resonance imaging (MRI) in depicting this early joint involvement and to establish a risk-profile for the individual patient.

Methods: Fifty patients (13 men and 37 women). mean age of 58.2 years (range 36-79 years) with clinical and laboratory evidence of ERA (mean disease duration $<12$ months) were included in our study. MRI of the atlantoaxial joint was performed in all patients. The MRI features were correlated with clinical, radiological and biochemical variables. All patients underwent radiographic examination of the hands, wrists and feet. The assessment of the structural damage was carried out by two experienced readers, according to simple erosion narrowing scores (SENS).

Results: Twelve (24\%) of the 50 patients with early ERA had positive MR findings. In all cases the MR showed pannus surrounded the dents, with additional erosions in 8 patients, bone marrow oedema at atlantoaxial in 9 patients and an abnormal cervico-medullary angle $\left(<135^{\circ}\right)$, in 2 patients. Compared with patients without cervical involvement, these 12 patients showed significantly higher antiCCP antibodies (ACPA) title [mean 200.25 UI (SD 262.44) vs. mean 22.05 (SD
40.21) $(\mathrm{p}<0.001)$; higher swollen joint count (SJC) [mean 13.66 (SD 3.39) vs mean 8.65 (SD 3.38) $(\mathrm{p}<0.001)$; higher Ritchie Articular Index (RAI) [mean 33.25 (SD 5.94) vs. mean 20.86 (SD 4.22) ( $p=0.047)$; higher $\mathrm{GH}$ [mean 69.58 (SD 13.49 ) vs. mean 45.92 (SD 9.55) $(p<0.001)$; higher Disease Activity Score (DAS) in 44 joints level [mean 5.72 (SD 0.44) vs. mean 4.52 (SD 0.53) $(p<0.001)$; highe Health Assessment Questionnaire Disability Index (HAQ-DI) [mean 1.55 (SD $0.37)$ vs. mean 1.09 (SD 0.33) $(p<0.001)$, and higher simple erosion narrowing (SENS) scores [mean 15.83 (SD 4.52) vs mean 7.71 (SD 3.43) $(p<0.001)$. Multivariate analysis showed meaningful relationship between ACPAs, high level of DAS and the presence of hand and wrist erosive lesions (SENS) with cervical involvement.

Conclusions: Our results showed that ERA patients with higher disease activity and advanced peripheral erosiveness are indicators of higher risk of early involvement of the atlantoaxial inflammatory synovitis. In daily clinical practice the MRI of cervical spine it should be proposed in patients with prognostic factors of unfavourable disease evolution, even if asymptomatic.

\section{REFERENCES:}

[1] Zoli A, Priolo F, Galossi A, Altomonte L, Di Gregorio F, Cerase A, et al. Craniocervical junction involvement in rheumatoid arthritis: a clinical and radiological study. J Rheumatol 2000;27:1178-1182.

[2] Joaquim AF, Appenzeller S. Cervical spine involvement in rheumatoid arthritis - a systematic review. Autoimmun Rev 2014;13:1195-1202.

Disclosure of Interest: None declared

DOI: 10.1136/annrheumdis-2018-eular.5453

\section{SAT0102 PRISTANE-INDUCED ARTHRITIS IN DARK AGOUTI RAT: A NEW ANIMAL MODEL TO STUDY CARDIOVASCULAR DYSFUNCTION IN RHEUMATOID ARTHRITIS}

M. Chouk ${ }^{1,2}$, R. Bordy ${ }^{2}$, J. Moretto ${ }^{2}$, M. Tournier-Nappey ${ }^{2}$, C. Prati ${ }^{1,2}$

D. Wendling ${ }^{1,3}$, P. Totoson ${ }^{2}$, C. Demougeot ${ }^{2} .{ }^{1}$ CHRU Jean Minjoz, Besançon;

${ }^{2}$ Pepite EA4267, Fhu Increase, Bourgogne Franche-Comté University, ${ }^{3} E A 4266$,

Bourgogne Franche-Comté University, Besançon, France

Background: Rheumatoid arthritis (RA) is characterised by an increased cardiovascular (CV) mortality. Animal models provide the opportunity to study CV features in RA, however, most used animal models develop a "monophasic" arthritis, making those models inappropriate for long-term studies on CV impairments.

Objectives: The aim of this study was to characterise vascular function and cardio-metabolic parameters in the "chronic" model of pristane-induced arthritis (PIA) in Dark Agouti (DA) rats.

Methods: 80 rats DA received an intradermal injection of $150 \mu \mathrm{L}$ of pristane (PIA) or of saline solution (controls) at day 0 . Arthritis score was daily followed. Acetylcholine (Ach) and sodium nitroprusside (SNP) -induced vasorelaxation were studied in macrovascular (aortic rings pre-contracted with serotonin) and in microvascular levels (mesenteric artery segments pre-contracted with phenylephrine) at day 28 (acute phase) and day 120 (chronic phase). Radiographic score, circulating markers of inflammation, lipid and glucose levels were also measured.

Results: PIA rats developed an acute arthritis phase from day 13 to day 50 followed by a remission phase, then by a chronic arthritis phase from day 70 to day 120. Radiographic score was higher in chronic than in acute phase in PIA $(p<0.001)$. Levels of IL-6, total cholesterol and triglycerides were higher in PIA than in controls at both phases $(p<0.001)$ whereas plasma myeloperoxidase activity and glycaemia were unchanged. Adiponectine levels were lower in PIA compared to controls in acute $(p<0.001)$ but not in chronic phase. Ach-induced vasorelaxation in macrovascular bed was significantly reduced in PIA compared to controls in acute $(p<0.05)$ but not in chronic phase. Furthermore, an altered Ach-induced vasorelaxation was shown in microvascular bed in PIA in chronic $(p<0.001)$ but not in acute phase. No altered SNP-induced vasorelaxation was observed between groups at both phases in both vascular beds. Endothelial function (EF) negatively correlated with arthritis score $(p<0.001), I L-6(p<0.05)$ and total cholesterol $(p<0.05)$ levels in macrovascular but not in microvascular bed No correlation was found between EF and myeloperoxidase activity, adiponectin and triglycerides levels in both vascular beds.

Conclusions: PIA model shares several features of the CV alterations in RA: an endothelial dysfunction at the micro- and macrovascular level with independency of course among these vascular beds, a link between inflammation and macrovascular endothelial dysfunction, associated with low lipid levels. These data suggest that this model would be very useful for long-term pharmacological studies as well for deciphering the complex pathophysiology of increased CV risk in RA.

Disclosure of Interest: None declared

DOI: 10.1136/annrheumdis-2018-eular.3619 